\title{
Microplastic pollution in freshwater ecosystems: A case study from Turkey
}

\section{Tatlısu ekosistemlerinde mikroplastik kirliliği: Türkiye'den bir örnek çalışma}

\section{Şeyda Erdoğan}

Abstract: Microplastic pollution has increased rapidly over recent decades and accepted as an emerging thread. However, the effects and dimensions of microplastic pollution on aquatic ecosystems have not been fully understood yet. Most of these few studies have been carried out in marine ecosystems and the number of studies on freshwater are very limited. In this study, microplastic $(<5 \mathrm{~mm})$ pollution level of surface water samples taken from Cevdet Pond (Yozgat/Turkey) was investigated. Water samples $(150 \mathrm{~L}$ ) were taken from 5 stations and microplastic particles were extracted via density separation method. Random particles were examined both visually and spectrophotometrically ( $\mu$-Raman). According to station averages, there were 233 microplastic particles in $1 \mathrm{~m}^{3}$ of the pond water. Highest number of MP particles observed in 100-250 $\mu \mathrm{m}(56 \%)$ size class. Most abundant microplastic type and colour are fiber $(91 \%)$ and blue $(36 \%)$ respectively. Polypropylene (50\%) and polyethylene (40\%) were the most abundant type of polymers according to $\mu$-Raman analysis. The presence of microplastic pollution in an area where human impact is relatively low, indicates the prevalence of microplastic pollution in freshwater ecosystems.

Keywords: Microplastic pollution, $\mu$-Raman, plastic waste, freshwater, pond

Öz: Mikroplastik kirliliği son yıllarda hızı bir şekilde artış göstermiş̧tir ve yeni ortaya çıkan tehditlerden biri olarak kabul edilmektedir. Ancak mikroplastik kirliliğinin sucul ekosistemlerdeki boyutları henüz tam olarak bilinmemektedir. Az sayıda mevcut olan çalıșmanın büyük bir çoğunluğu denizel ekosistemlerde gerçekleştirilmiştir ve tatlı su alanında yapılan çalışma sayısı çok sınırlıdır. Çalışmada Cevdet Dündar Göleti (Yozgat/Türkiye) yüzey suyundan alınan örneklerinde mikroplastik $(<5 \mathrm{~mm})$ kirliliği araştırımıştı. 5 farklı istasyondan yüzeyden alınan su örnekleri $(150 \mathrm{~L})$ yoğunluğa bağlı ayırma yöntemi kullanılarak ayrıştırımıştır. Partiküller hem görsel olarak hem spektrofotometrik ( $\mu$-Raman) yöntemler kullanılarak incelenmiştir. İstasyon ortalamalarına göre gölet suyunun $1 \mathrm{~m}^{3}$ 'ünde ortalama 233 mikroplastik parçacığı bulunmaktadır. Mikroplastik kirliliğinin en fazla gözlemlendiği boyut aralığı 100-250 $\mu \mathrm{m}(\% 56)$ dur. En yaygın gözlemlenen mikroplastik çeșidi ve rengi ise sırası ile fiber (\%91) ve mavi (\%36) renk olarak tespit edilmiștir. $\mu$-Raman analiz sonuçlarına göre en yaygın gözlemlenen mikroplastik türevleri ise polipropilen $(\% 50)$ ve polietilendir $(\% 40)$. Nispeten insan etkisinin az olduğu çalışma alanında mikroplastik kirliliğinin gözlemlenmesi mikroplastik kirliliğinin varlığını ortaya çıkarmaktadır.

Anahtar kelimeler: Mikroplastik kirliliği, $\mu$-Raman, plastic atık, tatı su, gölet

\section{INTRODUCTION}

American chemist Leo Hendrik's Baekeland application for a bakelite or the first synthetic plastic patent about 100 years ago (July 13,1907) can be considered as the beginning of the 'plastic age' (Crespy et al., 2008). Bakelite, was the pioneer of other polymer types and production of polymer derivatives started to increase rapidly in a short time period (Gowariker et al., 1986) The rapid increase of plastic production resulted in gradual plastic accumulation in different ecosystems, which in turn led to plastic-based environmental problems (Plastic Europe 2018). However, microplastic (MP) pollution in aquatic ecosystems has started to attract attention only in last decade (Andrady, 2011; Bergmann et al., 2015; Moore et al., 2011; Yin et al., 2019).
Because of the low production cost and durability, plastics are found in many substances that we use intensively in everyday life, such as food packs, clothing and cosmetic products as toothpaste and face wash gels (Auta et al., 2017; Royer et al., 2018). Although different definitions have been made for MP, plastics particles smaller than $5 \mathrm{~mm}$ are generally defined as MP (Blair et al., 2017). Polyethylene (PE), polypropylene (PP), polyethylene terephthalate (PET), polystyrene (PS), polyvinyl chloride (PVC), polyamide (PA) and polyvinyl alcohol (PVA) are the most commonly found polymer types in nature (Andrady, 2011; Avio et al., 2015). Plastics can be produced in small sizes (primary plastic) or they could divide into smaller particles over time (secondary plastic) (Blair et al., 2017). MPs can be carried to very long distances with different 
factors such as wind, water flow, air and biological carriers, which makes it difficult to determine the MP pollution level (Bergmann et al., 2015; Faure et al., 2015; Liebezeit \& Liebezeit, 2014; Rist et al., 2017).

Detailed investigations of plastic pollution in different ecosystems will reveal the real situation of the MP pollution (Lambert \& Wagner, 2018; Jambeck et al., 2015). According to a study results 4.8 to 12.7 million MP entered to the marine ecosystems only in 2010 (Jambeck et al., 2015). However, this is only 1.7 to $4.6 \%$ of the total plastic waste generated in studied countries, remained 98.3 to $95.4 \%$ of plastic waste substantially remained in terrestrial and freshwater ecosystems (Jambeck et al., 2015). While studies on plastic pollution are particularly conducted in marine ecosystems, studies in freshwater ecosystems are much more limited (Lambert \& Wagner, 2018). Since closed river basins act as a sink sources, MP pollution in lake ecosystems could be worse than marine ecosystems. Large amount of MPs already determined in lake and river ecosystems (Ballent et al., 2016; Castañeda et al., 2014; Corcoran et al., 2015; Faure et al., 2015; Fok \& Cheung, 2015). MP pollution was observed even in sub alpine lake (Imhof et al., 2013) and Antarctica where the human effect is relatively less (Reed et al., 2018). Nonetheless, studies to date have not been sufficient to elucidate the amount and effects of MPs on aquatic organisms especially in freshwater ecosystems (Andrady, 2011; Lambert \& Wagner, 2018). Only a few MP studies were conducted in Turkey (Gündoğdu, et al., 2018; Gündoğdu et al., 2017; Güven et al., 2017; Jovanović, 2017). However, MP pollution in natural freshwater systems has not been studied yet in Turkey. The purpose of this study is to determine presence and amount of MP pollution in Cevdet Dündar Pond which is located within the boundaries of Fatih Nature Park (Yozgat/Turkey) area. The results will help to contribute to filling knowledge gaps about the pollution. In addition, since the work area is under protection, the results will also contribute to the understanding of the dimensions of MP pollution.

\section{MATERIAL AND METHOD}

\section{Study area}

Cevdet Dündar pond is located in southern part of the Yozgat city $\left(39^{\circ} 48^{\prime} 46.13^{\prime \prime} \mathrm{N}, 34^{\circ} 49^{\prime} 22.30 " \mathrm{E}\right)$, on the Anatolian plateau in Central Turkey. Yozgat is a small city with a population of around 88000 . The pond is located within the boundaries of the Fatih Nature Park. The park is also adjacent to the Yozgat Pine Grove National Park which is Turkey's first National Park and way back to 1958. Arid-cold steppe climate with the rainy winters (mostly snow) and dry summers reigns in the area (Peel et al., 2007). The pond has only two seasonal inflows which were feed from precipitation. It is a small pond with 2.3 ha area, $9 \mathrm{~m}$ average depth and $1407 \mathrm{~m}$ altitude (Figure 1). The surrounding area of the lake is used as a recreational area, human population increase around the pond especially during the spring and summer seasons. Since the pond is located in protected area human impact is relatively low.

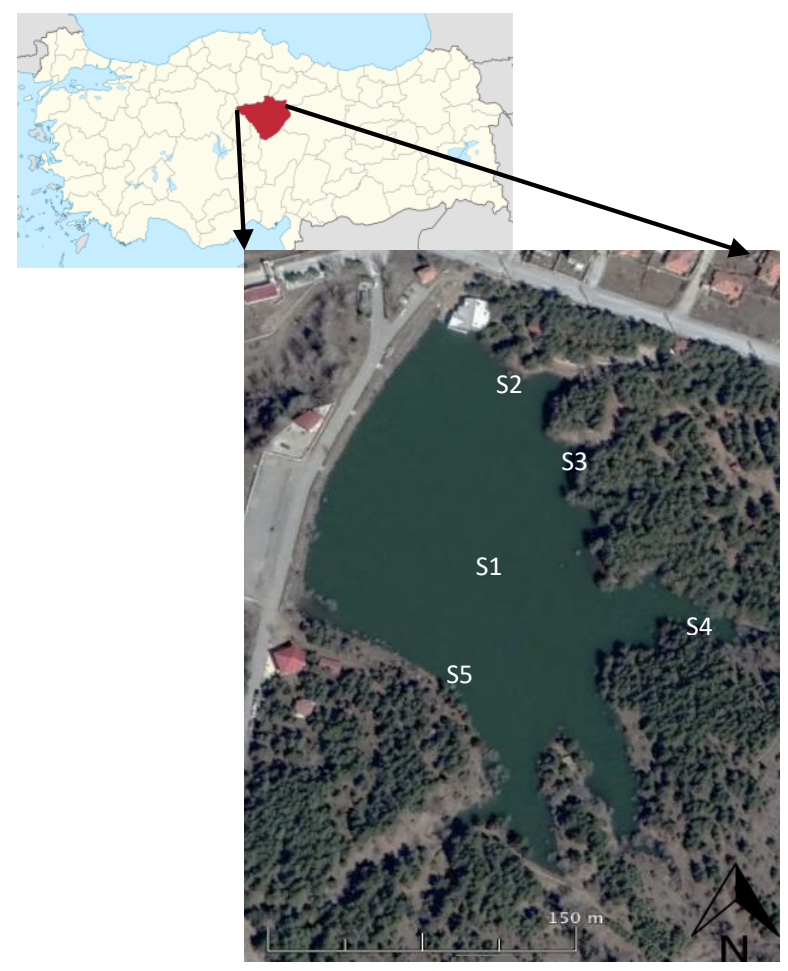

Figure 1. Cevdet Dündar pond location and sampling station (Sampling station were marked with "S")

\section{Sampling}

Surface water samples were taken via steel bucket from five different stations (Figure 1) (Yuan et al., 2019). 150 liters water sample, was filtered through stacked stainless steel sieves $(5000 \mu \mathrm{m}, 328 \mu \mathrm{m}$ and $61 \mu \mathrm{m}$ mesh size) with a diameter of $30 \mathrm{~cm}$. While particles stacked on $5000 \mu \mathrm{m}$ sieve were discarded, particles on $328 \mu \mathrm{m}$ and $61 \mu \mathrm{m}$ sieves were poured to the bottles and sieves were rinsed 3 times with ultrapure distilled water which formerly filtered through glass fiber (Whatman GF/F glass fiber filter, pore size $1.2 \mu \mathrm{m}$ ) filter (here after distilled water). After each sampling, the sieves were washed with pressurized tap water and passed through distilled water. Subsequently, samples were quickly brought into the laboratory and taken into glass beakers $(500 \mathrm{ml})$. The bottles were washed 3 times with distilled water to remove any remaining particles.

\section{Sample preparation}

Microplastic separation steps were performed according to NOAA laboratory methods (Masura et al., 2015). Bakers were covered with aluminium foil and placed into $90^{\circ} \mathrm{C}$ drying oven for 24 hours or more till all get dried. After wet peroxide oxidation step were applied for eliminate natural organic material; $20 \mathrm{ml} 0.05 \mathrm{M} \mathrm{Fe}$ (II) solution $\left(7.5 \mathrm{~g}\right.$ of $\mathrm{FeSO}_{4} 7 \mathrm{H}_{2} \mathrm{O}$ (= $278.02 \mathrm{~g} / \mathrm{mol}$ ) to $500 \mathrm{ml}$ of water and $3 \mathrm{ml}$ of concentrated sulfuric acid) and $20 \mathrm{ml} \mathrm{30 \%} \mathrm{hydrogen} \mathrm{peroxide} \mathrm{and} \mathrm{a} \mathrm{stir} \mathrm{bar}$ 
were added each baker than covered with a watchglass. The baker was heated to $75^{\circ} \mathrm{C}$ on a hot plate till bubbles appear. When bubbles appear the beaker was removed from the hot plate and kept in fume-hood till boiling stooped. If organic material still appears, the addition of peroxide was repeated. This process continued until all organic materials were invisible. Subsequently $6 \mathrm{gr}$ of $\mathrm{NaCl}$ was added to each $20 \mathrm{ml}$ of this mixture and allowed to dissolve at $75^{\circ} \mathrm{C}$. The mixture transferred to the density separator and allowed to settle for 24 hours and settled particles were drained. The presence of plastic particles in the settled part was examined, if any present, they were removed. The remaining solution was filtered through a pre-examined filter (mesh size $25 \mu \mathrm{m}$ ) (Masura et al., 2015). Filters were stored in pre-cleaned glass petri dishes for microscope analysis.

\section{Microscope examination and $\mu$-Raman analysis}

All filters were examined under stereo microscope (Olympus SZ61) (40x magnification). All types of the plastic particles were measured and their size, colour and types were recorded at the same time. Each filter counted 3 times.

The random particles were separated for [-Raman analysis. Renishaw InVia Raman spectrometer with microscope attachment $(50 x)$ was used. Excitation wavelength and exposure time were selected $514 \mathrm{~nm}$ and $10 \mathrm{~s}$ respectively. The applied spectrum range was $100-3500 \mathrm{~cm}-1$ and laser power was 0.1 to $5 \mathrm{~mW}$. Obtained spectra were analysed with Bio-Rad KnowltAll $®$ Informatics System Raman ID Expert (trial version) (Bio-Rad Laboratories, California, USA). The software gives similarity ratios by matching the obtained spectra with the potential reference spectra from its library (Turner et al., 2019). Base on this algorithm the software produces hit quality index ratio (HQI) between 0 (lowest similarity) and 1 (highest similarity). HQl higher than or equal to 0.7 was accepted as positive match (Kapp \& Yeatman, 2018).

During the all treatment processes (peroxide oxidation, settlement, drying oven, microscope examination) an empty glass petri dish (pre-cleaned and checked under microscope) were placed together with the samples. After all the processes petri dishes were also examined under microscope and observed number of plastic particles were subtracted from the total count. To prevent contamination, the laboratory did not used by other people during the counting process. Before counting all the lab surfaces were cleaned with alcohol 3 times. Additionally, cotton lab ware and sterile nitrile gloves were used during the all processes.

\section{Data analysis}

Differences among MP size, type and colour was tested statistically base on station data. Since data did not meet ANOVA assumptions Kruskal-Wallis test was used to analyze multiple comparisons. If there was a significance MannWhitney $U$ test applied with Bonferroni correction to adjust the probability $(p=0.05)$.

\section{RESULTS}

MP particles were observed in all water samples (Figure 2). Total counted MP number is 173 in all sampling stations. While highest MP number was observed in S1 (96) station, lowest number was observed in S5 (18) station. Detected MP number were 19, 21 and 19 for S2, S3 and S4 stations respectively. Total counted microplastic number in all stations were summed and were divided into five to find average MP abundance at each station. Average MP abundance was 35 for each station. Since 150 litres of pond water was filtered at each station, it can be calculated that there are 233 MP particles in per cubic meter of pond water

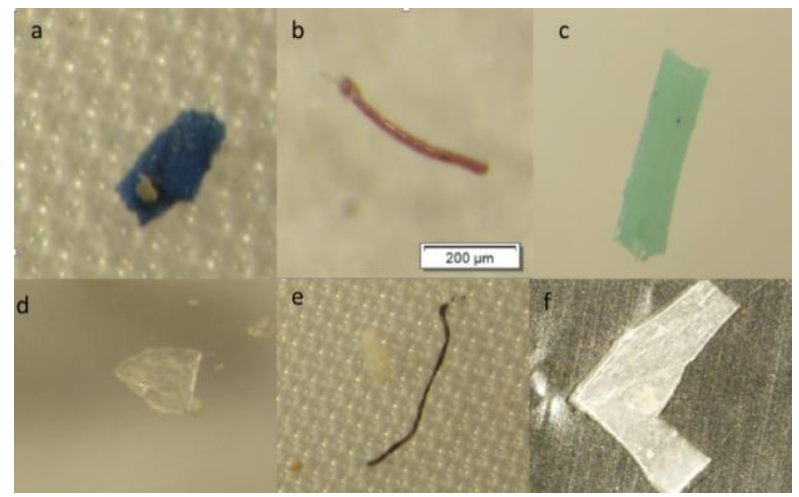

Figure 2. Microscope images of different MP types (a-d: fragment, be: fiber, c-f: film)

MPs were classified into 3 groups according to their size (61-100 $\mu \mathrm{m}, 100-250 \mu \mathrm{m}, 250-5000 \mu \mathrm{m})$ (Figure 3). Highest number of MP particles observed in 100-250 $\mu \mathrm{m}$ size class ( $n=$ $97,56 \%)$ and followed by $61-100 \mu \mathrm{m}(\mathrm{n}=44,25 \%), 250-5000$ $\mu \mathrm{m}(\mathrm{n}=32,18 \%)(p>0.05)$. 


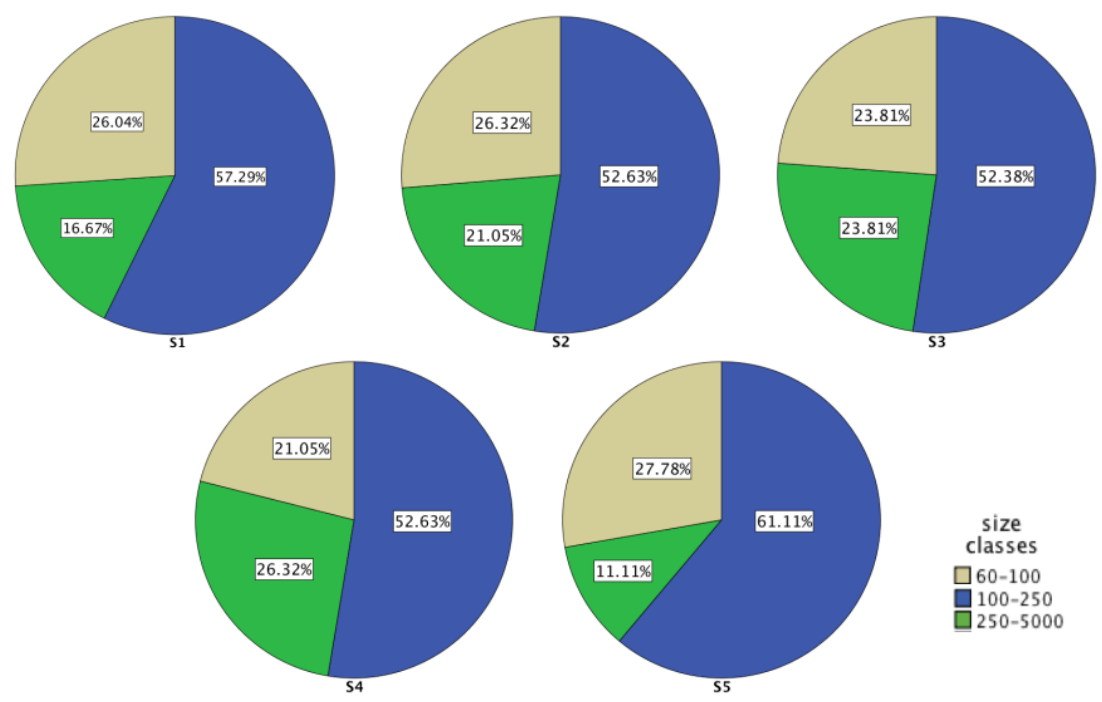

Figure 3. Size classes and frequencies of observed MPs from Cevdet Dündar Pond

Fiber was the most common MP type and formed $90.75 \%$ of all MP. On the other hand, fragment and film was less frequently observed and they only formed $8.09 \%$ and $1.16 \%$ of total MP respectively. Difference in terms of particle number between fiber-film $(p<0.004)$, and fiber-fragment $(p<0.03)$ was significant.
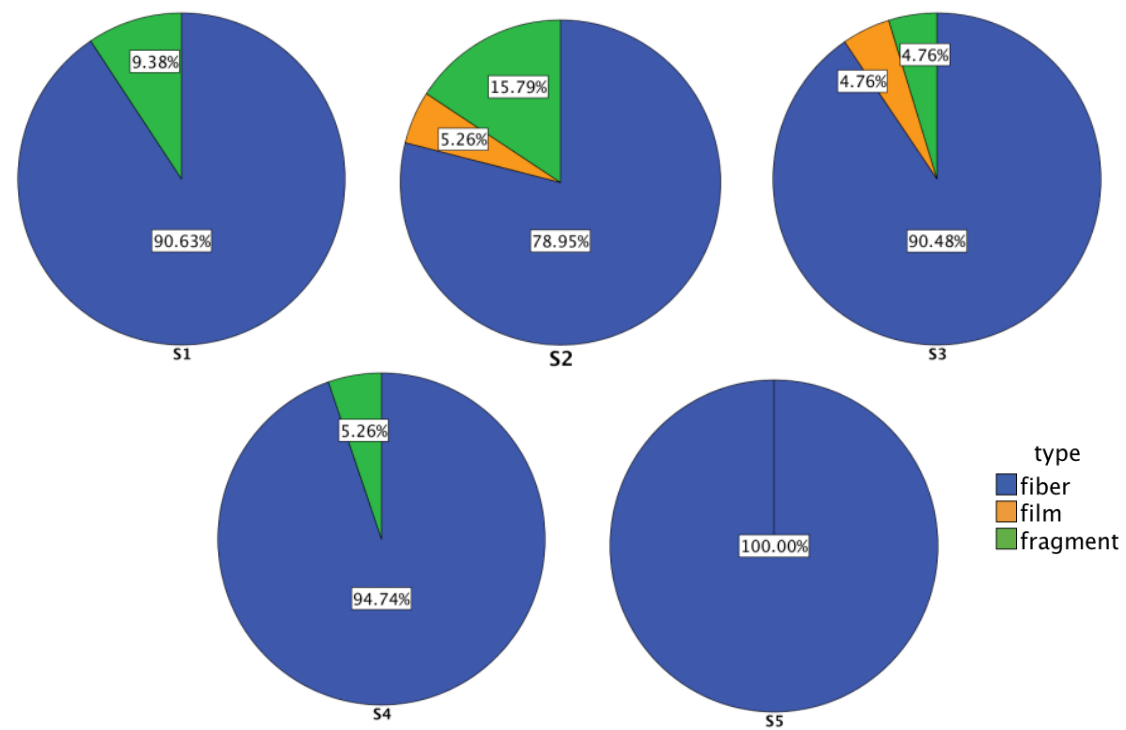

Figure 4. MP type percentages in water samples collected from Cevdet Dündar Pond

Colour distribution of MP particles in sampling stations were presented in Figure 5.

The highest observed colour is blue (36.42\%) and followed by transparent, black, green, white and yellow, their percentages in total $20.81 \%, \quad 19.08 \%, 5.78 \%, 5.20 \%$ and $4.05 \%$ respectively.

There was no significant difference in terms of particle number among MP colour groups in terms of number $(p>0.05)$. 


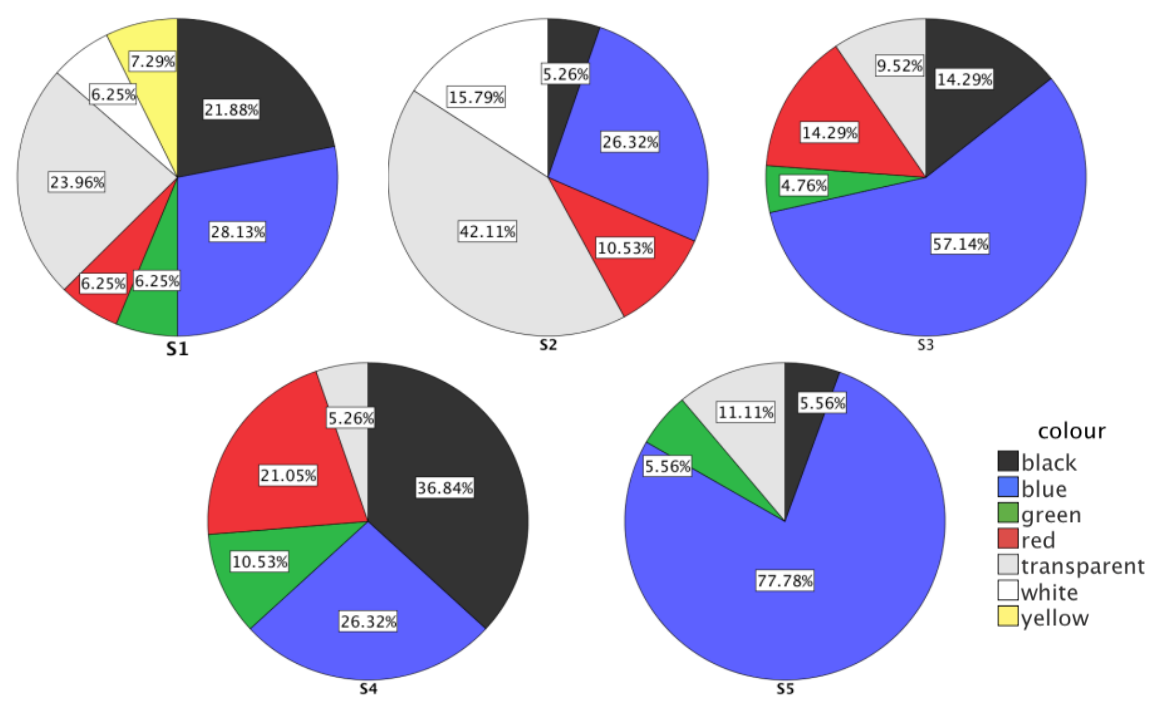

Figure 5. Proportion of MP colour distribution in water samples collected from Cevdet Dündar Pond

Random 10 MP particles were identified using $\mu$-Raman BioRad KnowltAll@ Informatics System - Raman ID Expert (trial version) (Bio-Rad Laboratories, California, USA). For all identified MP particles most common type of the plastic was polypropylene $(50 \%)$ followed by polyethylene $(40 \%)$ and polyamide (10\%) (Figure 6).
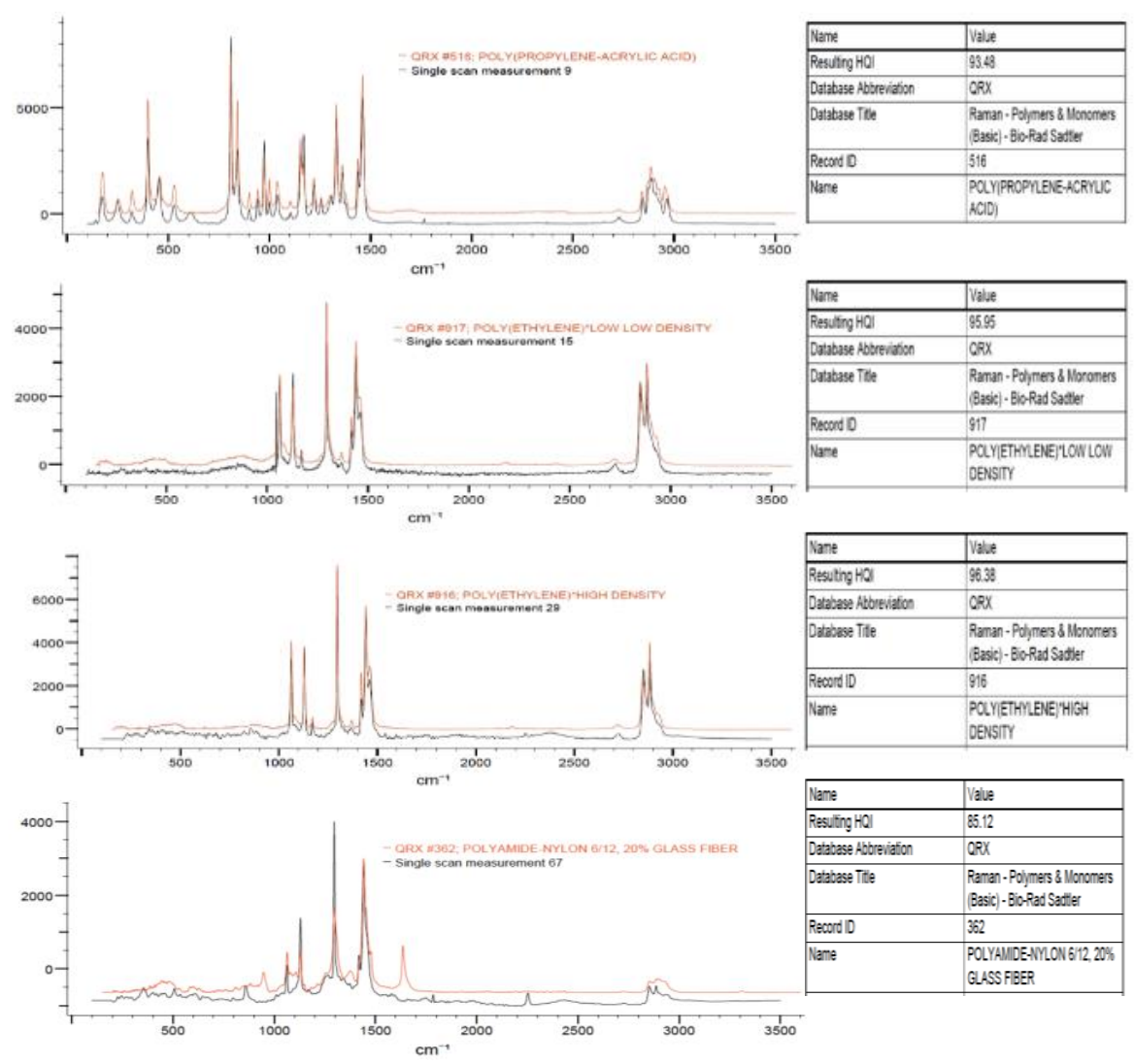

Figure 6. Example Raman spectra of selected MP particles (black: sample spectrum, red: matched library spectrum) 


\section{DISCUSSION}

MP pollution was observed in all sampling stations with different numbers. Average MP number per cubic meter is 233 , however it is relatively low compared to other freshwater studies (Table1).

As mentioned before the pond is located within a protected area and human impact is relatively less, however exemplary lakes (Table 1) were subjected to intense human activities and it could be the main reason of low MP number in the current study. Moreover, since different methods were applied, it is not possible to make a clear and accurate comparison with previous studies (Talvitie et al., 2015; Zhao et al., 2018). For instance, 5 different mesh size were used in the lakes in Table 1. Moreover, different factors like point pollution sources, hydrology, wind, population density and plastic properties may cause variability among different sampling areas (Luo et al., 2019; Mani et al., 2015; Xiong et al., 2018).

Table 1. MP abundance of freshwater lakes in different areas

\begin{tabular}{lcccc}
\hline Study Area & $\begin{array}{c}\text { Locati } \\
\text { on }\end{array}$ & $\begin{array}{c}\text { Mesh size } \\
(\mu \mathrm{m})\end{array}$ & MP number $\left(\mathrm{m}^{3}\right)$ & References \\
\hline Lake Bolsena & Italy & 300 & $57 \pm 241$ & Fischer et al.(2016) \\
\hline Lake Chiusi & Italy & 300 & $64 \pm 21$ & Fischer et al.(2016) \\
\hline Lake Ulansuhai & China & 48 & $1760-10170$ & Wang et al.(2019) \\
\hline Lake Taihu & China & 333 & $3400-24,800$ & Su et al.(2016) \\
\hline Lake Donting & China & 50 & $385 \pm 221.1$ & Wang et al.(2018) \\
\hline Lake Hong & China & 50 & $685.5 \pm 375.3$ & Wang et al.(2018) \\
\hline Lake Poyang & China & 50 & $5000-34000$ & Yuan et al.(2019) \\
\hline C. Dündar Pond & Turkey & 61 & 233 & This Study \\
\hline
\end{tabular}

Fiber was the most abundant type of MP in all stations (Figure 4), and it is also in accordance with the literature. Fiber could be originated from either primer or seconder plastic (Peters \& Bratton, 2016). Worldwide textile fiber production was over 90 million tons in 2016 alone (Gasperi et al., 2018) and domestic wastewater is known to contain a large amount of synthetic fiber, particularly from washing machine discharge (Salvador et al., 2017). However, it cannot be the case for our study since the pond is located in a protected area. On the other hand, plastics can also be transported by air. According to a study results $29-280$ (particles $/ \mathrm{m}^{2} / \mathrm{d}$ ) fiber particles found in atmospherics fallout (Gasperi et al., 2015). Therefore, airborne contamination may be one of the reason of the MP pollution in the pond. On the other hand, plastic products disposed around the pond (personal observation) could be another fiber source.

Different coloured MP particles were observed in samples and the most commonly observed colour is blue in general (Figure 5), and this is in agreement with other studies. The blue colour commonly used in many plastic products (Kosuth et al., 2018; Li et al., 2019; Zhang et al., 2017). In addition, a large portion of the plastic wastes observed around the pond were water bottles and almost all of them have blue lid while some of them are blue in colour (personal observation). The disintegration of blue coloured wastes over the time might be the main reason of abundance (Figueiredo \& Vianna, 2018). In addition, some studies have shown that aquatic organisms selectively digest blue coloured MPs (Devriese et al., 2015; Güven et al., 2017;
Karlsson et al., 2017). It could also be valid for aquatic organisms in Cevdet Dündar pond, but more detailed researches should be carried out to understand MP effect on living biota in the pond. While transparent and black coloured particles are the second and third most intensely observed colours, other colours represented by fewer records. Transparent colour is commonly used in disposable bags and they were abundant in the recreation area around the pond. The reason for the excessive observation of the black colour might be the road passing by the pond (Figure 1). According to a conducted study among 13 countries average plastic emission per Capita/year is $0.95 \mathrm{~kg}$ (Kole et al., 2017). Plastic release from car tires due to mechanical abrasion is a wellknown phenomenon, additionally its contribution to MP pollution have been suggested by several research (Sundt, et al., 2014; Lassen, et al., 2015; Siegfried, et al., 2017). The type of black particle analysed in our study was identified as polyamide, however it is not sufficient to make a valid decision, further detailed studies need to be carried out.

$\mu$-Raman method has been used frequently and successfully in MP identification (Anger et al., 2018; Gündoğdu, 2018; Wen et al., 2018; Xiong et al., 2018; Yin et al., 2019). In many previous studies, MP determination has been made only by visual identification (Desforges et al., 2014; Miranda \& de Carvalho-Souza, 2016; Rochman et al., 2015), however, many recent studies have added spectrophotometric methods ( $\mu$ Raman or FTIR) in addition to microscopic examination (Gündoğdu \& Çevik, 2017; Tsang et al., 2017; Wen et al., 
2018). However, since these methods are both expensive and time-consuming, only a portion of the samples or random particles can be analysed. In line with the many previous studies polypropylene (50\%) and polyethylene (40\%) were the most abundant polymer types in Cevdet Dündar pond (Figure 5) (Hidalgo et al., 2012; Zbyszewski et al., 2014). Polypropylene and polyethylene have been identified extensively in aquatic ecosystems and their usage areas are widespread. Plastic bottles, plastic bags and containers are examples of the uses of these polymer types (Desforges et al., 2014).

This study also has drawbacks. First of all, MP sampling conducted only once (March, 2019) and as a consequence of water level change during the rainy and dry season MP abundance might change. According to a conducted study the pond surface area decreased $7.8 \%$ during the dry summer season in 2019 (submitted data). Consequently, if the sampling was conducted during the summer period, an increase in the amount of MP was likely due to the decrease in pond surface area. However, majority of the studies were conducted with a single sampling and widely available in the literature both for freshwater and marine ecosystems (Gündoğdu \& Çevik, 2017;

\section{REFERENCES}

Andrady, A.L. (2011). Microplastics in the marine environment. Marine Pollution Bulletin, 62(8), 1596-1605. DOI: 10.1016/j.marpolbul.2011.05.030

Anger, P.M., von der Esch, E., Baumann, T., Elsner, M., Niessner, R. \& Ivleva, N. P. (2018). Raman microspectroscopy as a tool for microplastic particle analysis. Trends in Analytical Chemistry, 109, 214-226. DOI: 10.1016/j.trac.2018.10.010

Auta, H.S., Emenike, C.U. \& Fauziah, S.H. (2017). Distribution and importance of microplastics in the marine environment $A$ review of the sources, fate, effects, and potential solutions. Environment International, 102, 165-176. DOI: 10.1016/j.envint.2017.02.013

Avio, C.G., Gorbi, S., Milan, M., Benedetti, M., Fattorini, D., D’Errico, G. Pauletto, M., Bargelloni, L. \& Regoli, F. (2015). Pollutants bioavailability and toxicological risk from microplastics to marine mussels. Environmental Pollution, 198, 211-222. DOI: 10.1016/j.envpol.2014.12.021

Ballent, A., Corcoran, P. L., Madden, O., Helm, P. A. \& Longstaffe, F.J. (2016) Sources and sinks of microplastics in Canadian Lake Ontario nearshore, tributary and beach sediments. Marine Pollution Bulletin, 110(1), 383-395. DOI: 10.1016/j.marpolbul.2016.06.037

Bergmann, M., Gutow, L. \& Klages, M. (2015). Marine anthropogenic litter. Springer, 1-447. DOI: 10.1007/978-3-319-16510-3

Bio-Rad KnowltAll囚 Informatics System - Raman ID Expert. Alıntılanma adresi: $\quad$ https://www.bio-rad.com/en-tr/product/raman-spectraldatabases?ID=N0ZXPS4VY (10.08.2019).

Blair, R. M., Waldron, S., Phoenix, V. \& Gauchotte-Lindsay, C. (2017). Microand Nanoplastic Pollution of Freshwater and Wastewater Treatment Systems. Springer Science Reviews, 5(1), 19-30. DOI: 10.1007/s40362-017-0044-7

Castañeda, R.A., Avlijas, S., Simard, M.A., Ricciardi, A. \& Smith, R. (2014). Microplastic pollution in St. Lawrence River sediments. Canadian Journal of Fisheries and Aquatic Sciences, 71(12), 1767-1771. DOI: 10.1139/cjfas-2014-0281

Corcoran, P.L., Norris, T., Ceccanese, T., Walzak, M.J., Helm, P.A. \& Marvin, C.H. (2015). Hidden plastics of Lake Ontario, Canada and their potential
Yin et al., 2019; Scopetani et al., 2019; Wang et al., 2019; Li et al., 2019; Egessa et al., 2020). Moreover, there is a possibility of error in the microscope identification. Only small amount of particles (10 particles) could analysed with Raman spectroscopy due to financial limitations.

Despite the mentioned drawbacks conducted study elucidate potential MP distribution in freshwater ecosystems. Most of the MP studies on aquatic ecosystems have been carried out in marine ecosystems and the studies on freshwater ecosystems are limited. In addition, limited studies on freshwater were carried out in areas where human impact was observed intensively. The number of studies conducted in regions where human impact is limited is much less. Therefore, this study reveals that MP pollution is observed even in areas with limited human impact and contributes to a better understanding of the extent of MP pollution.

\section{ACKNOWLEDGEMENTS}

The author declares no conflict of interest. I am grateful to Dr. Hatice Baş and Dr. Hatice Arı for their help during the field work and $\mu$-Raman analysis. preservation in the sediment record. Environmental Pollution, 204, 17-25. DOI: 10.1016/j.envpol.2015.04.009

Crespy, D., Bozonnet, M. \& Meier, M. (2008). 100 Years of Bakelite, the Material of a 1000 Uses. Angewandte Chemie International Edition, 47(18), 3322-3328. DOI: 10.1002/anie.200704281

Desforges, J.P.W., Galbraith, M., Dangerfield, N. \& Ross, P.S. (2014). Widespread distribution of microplastics in subsurface seawater in the NE Pacific Ocean. Marine Pollution Bulletin, 79(1), 94-99. DOI: 10.1016/j.marpolbul.2013.12.035

Devriese, L. I., van der Meulen, M. D., Maes, T., Bekaert, K., Paul-Pont, I., Frère, L., RObbens, J., Vethaak, A. D. (2015). Microplastic contamination in brown shrimp (Crangon crangon, Linnaeus 1758) from coastal waters of the Southern North Sea and Channel area. Marine Pollution Bulletin, 98(1-2), 179-197. DOI: 10.1016/j.marpolbul.2015.06.051

Egessa, R., Nankabirwa, A., Basooma, R.\& Nabwire, R. (2020). Occurrence, distribution and size relationships of plastic debris along shores and sediment of northern Lake Victoria, Environmental Pollution, 257, 113442. DOI: 10.1016/j.envpol.2019.113442

Faure, F., Demars, C., Wieser, O., Kunz, M. \& De Alencastro, L. F. (2015). Plastic pollution in Swiss surface waters: Nature and concentrations, interaction with pollutants. Environmental Chemistry, 12(5), 582-591. DOI: $10.1071 /$ EN14218

Figueiredo, G. M. \& Vianna, T. M. P. (2018). Suspended microplastics in a highly polluted bay: Abundance, size, and availability for mesozooplankton. Marine Pollution Bulletin, 135, 256-265. DOI: 10.1016/j.marpolbul.2018.07.020

Fischer, E. K., Paglialonga, L., Czech, E. \& Tamminga, M. (2016). Microplastic pollution in lakes and lake shoreline sediments - A case study on Lake Bolsena and Lake Chiusi (central Italy). Environmental Pollution, 213, 648-657. DOI: 10.1016/j.envpol.2016.03.012

Fok, L. \& Cheung, P. K. (2015). Hong Kong at the Pearl River Estuary: A hotspot of microplastic pollution. Marine Pollution Bulletin, 99(1-2), 112118. DOI: $10.1016 /$ j.marpolbul.2015.07.050 
Gasperi, J., Dris, R., Mirande-Bret, C., Mandin, C., Langlois, V. \& Tassin, B. (2015). First overview of microplastics in indoor and outdoor air. 15th European Chemical Society, International Conference on Chemistry and the Environment.

Gasperi, J., Wright, S.L., Dris, R., Collard, F., Mandin, C., Guerrouache, M., Langlois, V., Kelly F.J., Tassin, B. (2018). Microplastics in air: Are we breathing it in? Current Opinion in Environmental Science \& Health, 1, 15. DOI: 10.1016/j.coesh.2017.10.002

Google Earth 7. 2019. Cevdet Dündar Pond $39^{\circ} 48^{\prime} 46.13^{\prime \prime N}, 34^{\circ} 49^{\prime} 22.30^{\prime \prime E}$, elevation $1407 \mathrm{~m}$. Terrain Layer <http://www.google.com/earth/index.html>> [Viewed, 27 February 2020].

Gowariker, V.R., Viswanathan, N. V., Sreedhar, J., 1986. Polymer Science. Halsted Press (John Wiley \& Sons), New York, pp. 1-505.

Gündoğdu, S. (2018). Contamination of table salts from Turkey with microplastics. Food Additives and Contaminants - Part A Chemistry, Analysis, Control, Exposure and Risk Assessment, 35(5), 1006-1014. DOI: 10.1080/19440049.2018.1447694

Gündoğdu, S. \& Çevik, C. (2017). Micro- and mesoplastics in Northeast Levantine coast of Turkey: The preliminary results from surface samples. Marine Pollution Bulletin, 118(1-2), 341-347. DOI: 10.1016/j.marpolbul.2017.03.002

Gündoğdu, S., Çevik, C., Güzel, E. \& Kilercioğlu, S. (2018). Microplastics in municipal wastewater treatment plants in Turkey: a comparison of the influent and secondary effluent concentrations. Environmental Monitoring and Assessment, 190(11), 626. DOI: 10.1007/s10661-018-7010-y

Gündoğdu, S., Çevik, C. \& Karaca, S. (2017). Fouling assemblage of benthic plastic debris collected from Mersin Bay, NE Levantine coast of Turkey. Marine Pollution Bulletin, 124(1), 147-154.

DOI: 10.1016/j.marpolbul.2017.07.023

Güven, O., Gökdağ, K., Jovanović, B. \& Kıdeyş, A. E. (2017). Microplastic litter composition of the Turkish territorial waters of the Mediterranean Sea, and its occurrence in the gastrointestinal tract of fish. Environmental Pollution, 223, 286-294. DOI: 10.1016/j.envpol.2017.01.025

Hidalgo-Ruz, V., Gutow, L., Thompson, R.C. \& Thiel, M. (2012). Microplastics in the Marine Environment: A Review of the Methods Used for Identification and Quantification. Environmental Science and Technology, 46, 3060-3075. DOI: 10.1021/es2031505

Imhof, H. K., Ivleva, N. P., Schmid, J., Niessner, R. \& Laforsch, C. (2013). Contamination of beach sediments of a subalpine lake with microplastic particles. Current Biology, 23(19), R867-R868. DOI: 10.1016/j.cub.2013.09.001

Jambeck, J. R., Geyer, R., Wilcox, C., Siegler, T. R., Perryman, M., Andrady, A., Narayan, R., Law, K. L. (2015). Marine pollution. Plastic waste inputs from land into the ocean. Science, 347(6223), 768-771. DOI: 10.1126/science.1260352

Jovanović, B. (2017). Ingestion of microplastics by fish and its potential consequences from a physical perspective. Integrated Environmental Assessment and Management, 13(3), 510-515. DOI: 10.1002/ieam.1913

Kapp, K. J. \& Yeatman, E. (2018). Microplastic hotspots in the Snake and Lower Columbia rivers: A journey from the Greater Yellowstone Ecosystem to the Pacific Ocean. Environmental Pollution, 241, 10821090. DOI: 10.1016/j.envpol.2018.06.033

Karlsson, T. M., Vethaak, A. D., Almroth, B. C., Ariese, F., van Velzen, M., Hassellöv, M. \& Leslie, H. A. (2017). Screening for microplastics in sediment, water, marine invertebrates and fish: Method development and microplastic accumulation. Marine Pollution Bulletin, 122(1-2), 403-408. DOl: 10.1016/j.marpolbul.2017.06.081

Kole, P.J., Löhr, A.J., Van Belleghem, F. \& Ragas, A., 2017. Wear and Tear of Tyres: A Stealthy Source of Microplastics in the Environment. Int. J. Environ. Res. Public Health 14, 1265. DOI: 10.3390/ijerph14101265

Kosuth, M., Mason, S.A. \& Wattenberg, E. V. (2018). Anthropogenic contamination of tap water, beer, and sea salt. Public Library of Science, 13(4), 1-18. DOI: 10.1371/journal.pone.0194970
Lambert S. \& Wagner, M. (2018). Microplastics Are Contaminants of Emerging Concern in Freshwater Environments: An Overview. In: Wagner M., Lambert S. (eds) Freshwater Microplastics. The Handbook of Environmental Chemistry, vol 58. Springer, Cham. DOI: 10.1007/978-3-319-61615-5_1

Lassen, C., Hansen, S. F., Magnusson, K., Hartmann, N. B., Rehne Jensen, P., Nielsen, T.G. \& Brinch, A. (2015). Microplastics: Occurrence, Effects and Sources of Releases to the Environment in Denmark; Danish Environmental Protection Agency: Copenhagen, Denmark, 2015.

Li, L., Geng, S., Wu, C., Song, K., Sun, F., Visvanathan, C., Fazh', X. \& Wang, Q. (2019). Microplastics contamination in different trophic state lakes along the middle and lower reaches of Yangtze River Basin. Environmental Pollution, 254, 112951.

DOI: 10.1016/j.envpol.2019.07.119

Liebezeit, G. \& Liebezeit, E. (2014). Synthetic particles as contaminants in German beers. Food Additives and Contaminants - Part A Chemistry, Analysis, Control, Exposure and Risk Assessment, 31(9), 1574-1578. DOI: 10.1080/19440049.2014.945099

Luo, W., Su, L., Craig, N. J., Du, F., Wu, C. \& Shi, H. (2019). Comparison of microplastic pollution in different water bodies from urban creeks to coastal waters. Environmental Pollution, 246, 174-182. DOI: 10.1016/J.ENVPOL.2018.11.081

Mani, T., Hauk, A., Walter, U. \& Burkhardt-Holm, P. (2015). Microplastics profile along the Rhine River. Scientific Reports, 5 (December), 1-7. DOI: $10.1038 /$ srep 17988

Miranda, D. de A. \& de Carvalho-Souza, G. F. (2016). Are we eating plasticingesting fish? Marine Pollution Bulletin, 103(1-2), 109-114. DOI: 10.1016/j.marpolbul.2015.12.035

Moore, C. J., Lattin, G. L. \& Zellers, A. F. (2011). Quantity and type of plastic debris flowing from two urban rivers to coastal waters and beaches of Southern California. Revista de Gestão Costeira Integrada, 11(1), 65-73. DOI: 10.5894/rgci194

Masura, J., Baker, J., Foster, G., Arthur, C. (2015). Laboratory methods for the analysis of microplastic in the marine environment: recommendations for quantifying synthetic particles in waters and sediments. NOAA Technical Memorandum NOS-OR\&R-48.

NOAA (National Oceanic and Atmospheric Administration) (2008). Proceedings of the International Research Workshop on the occurrence, effects and fate of microplastic marine debris. In: Arthur C, Baker J, Bamford H. (Eds.), Technical Memorandum NOS- OR\&R-30. University of Washington Tacoma, Tacoma, WA, USA September 9-11. pp.1-49.

Olesen, K. B., van Alst, N., Simon, M., Vianello, A., Liu, F. \& Vollertsen, J. (2017). Analysis of Microplastics using FTIR Imaging: Application Note. Agilent Application Note Environment.

Plastic Europe, 2018. Plastics-the Facts 2017 An analysis of European plastics production, demand and waste data. Annual Report. Association of Plastic Manufacturers, Brussels, pp. 1-41.

Peel, M. C., Finlayson, B. L. \& McMahon, T. A. (2007). Updated world map of the Köppen-Geiger climate classification. Hydrology and Earth System Sciences, 11(5), 1633-1644. DOI: 10.5194/hess-11-1633-2007

Peters, C.A. \& Bratton, S.P. (2016). Urbanization is a major influence on microplastic ingestion by sunfish in the Brazos River Basin, Central Texas, USA. Environmental Pollution, 210, 380-387. DOI: 10.1016/j.envpol.2016.01.018

Reed, S., Clark, M., Thompson, R. \& Hughes, K. A. (2018). Microplastics in marine sediments near Rothera Research Station, Antarctica. Marine Pollution Bulletin, 133, 460-463. DOI: 10.1016/j.marpolbul.2018.05.068

Rist, S., Baun, A. \& Hartmann, N. B. (2017). Ingestion of micro- and nanoplastics in Daphnia magna - Quantification of body burdens and assessment of feeding rates and reproduction. Environmental Pollution, 228, 398-407. DOI: 10.1016/j.envpol.2017.05.048

Rochman, C.M., Tahir, A., Williams, S.L., Baxa, D.V., Lam, R., Miller, J.T., Teh, F.C., Werorilangi, S. \& Teh, S.J. (2015). Anthropogenic debris in seafood: Plastic debris and fibers from textiles in fish and bivalves sold for human consumption. Scientific Reports, 5. DOI: 10.1038/srep14340 
Royer, S.-J., Ferrón, S., Wilson, S.T. \& Karl, D.M. (2018). Production of methane and ethylene from plastic in the environment. Public Library of Science, 13(8), 1-13. DOI: 10.1371/journal.pone.0200574

Salvador Cesa, F., Turra, A. \& Baruque-Ramos, J. (2017). Synthetic fibers as microplastics in the marine environment: A review from textile perspective with a focus on domestic washings. Science of The Total Environment, 598, 1116-1129. DOI: 10.1016/j.scitotenv.2017.04.172

Scopetani, C., Chelazzi, D., Cincinelli, A., Esterhuizen-Londt M. (2019). Assessment of microplastic pollution: occurrence and characterisation in Vesijärvi lake and Pikku Vesijärvi pond, Finland. Environmental Monitoring Assessment, 191, 652. DOI: 10.1007/s10661-019-7843-z

Siegfried, M., Koelmans, A.A., Besseling, E. \& Kroeze, C. (2017). Export of microplastics from land to sea. A modelling approach. Water Research. 127, 249-257. DOI: 10.1016/J.WATRES.2017.10.011

Su, L., Xue, Y., Li, L., Yang, D., Kolandhasamy, P., Li, D. \& Shi, H. (2016). Microplastics in Taihu Lake, China. Environmental Pollution, 216, 711 719. DOI: 10.1016/j.envpol.2016.06.036

Sundt, P., Schulze, P. E., Syversen, F. (2014). Sources of MicroplasticsPollution to the Marine Environment, Norway: Mepex Consult.

Talvitie, J., Heinonen, M., Pääkkönen, J. P., Vahtera, E., Mikola, A., Setälä, O. \& Vahala, R. (2015). Do wastewater treatment plants act as a potential point source of microplastics? Preliminary study in the coastal Gulf of Finland, Baltic Sea. Water Science and Technology, 72(9), 1495-1504. DOI: 10.2166/wst.2015.360

Tsang, Y.Y.Y., Mak, C.W.W., Liebich, C., Lam, S.W.W., Sze, E.T.P.T.-P. \& Chan, K.M.M. (2017). Microplastic pollution in the marine waters and sediments of Hong Kong. Marine Pollution Bulletin, 115(1-2), 20-28. DOI: 10.1016/J.MARPOLBUL.2016.11.003

Turner, S., Horton, A.A., Rose, N.L. \& Hall, C. (2019). A temporal sediment record of microplastics in an urban lake, London, UK. Journal of Paleolimnology, 61, 449-462. DOI: 10.1007/s10933-019-00071-7

United Nations Environment Programme. 2014. Plastic waste causes financial damage of US $\$ 13$ billion to marine ecosystems each year as concern grows over microplastics. [cited 2019 August 19]. https://www.unenvironment.org/news-and-stories/press-release/plasticwaste-causes-financial-damage-us13-billion-marine-ecosystems
Wang, W., Yuan, W., Chen, Y. \& Wang, J. (2018). Microplastics in surface waters of Dongting Lake and Hong Lake, China. Science of The Total Environment, 633, 539-545. DOI: 10.1016/J.SCITOTENV.2018.03.211

Wang, Z., Qin, Y., Li, W., Yang, W., Meng, Q. \& Yang, J. (2019). Microplastic contamination in freshwater: first observation in Lake Ulansuhai, Yellow River Basin, China. Environmental Chemistry Letters, 17(4), 1821-1830. DOI: 10.1007/s10311-019-00888-8

Wen, X., Du, C., Xu, P., Zeng, G., Huang, D., Yin, L., Yin, Q., Hu, L., Wan, J., Zhang, J., Tan, S. \& Deng, R. (2018). Microplastic pollution in surface sediments of urban water areas in Changsha, China: Abundance, composition, surface textures. Marine Pollution Bulletin. 136, 414-423 DOI: 10.1016/j.marpolbul.2018.09.043

Xiong, X., Zhang, K., Chen, X., Shi, H., Luo, Z. \& Wu, C. (2018). Sources and distribution of microplastics in China's largest inland lake-Qinghai Lake. Environmental Pollution, 235, 899-906.

DOI: 10.1016/j.envpol.2017.12.081

Yin, L., Jiang, C., Wen, X., Du, C., Zhong, W., Feng, Z., Long, Y., Ma, Y. (2019). Microplastic pollution in surface water of urban lakes in changsha, china. International Journal of Environmental Research and Public Health, 16(9), 1650. DOI: 10.3390/ijerph16091650

Yuan, W., Liu, X., Wang, W., Di, M. \& Wang, J. (2019). Microplastic abundance, distribution and composition in water, sediments, and wild fish from Poyang Lake, China. Ecotoxicology and Environmental Safety, 170, 180-187. DOI: 10.1016/J.ECOENV.2018.11.126

Zbyszewski, M., Corcoran, P. L. \& Hockin, A. (2014). Comparison of the distribution and degradation of plastic debris along shorelines of the Great Lakes, North America. Journal of Great Lakes Research, 40(2), 288-299. DOI: $10.1016 / j$.jglr.2014.02.012

Zhang, K., Xiong, X., Hu, H., Wu, C., Bi, Y., Wu, Y., ... Liu, J. (2017). Occurrence and Characteristics of Microplastic Pollution in Xiangxi Bay of Three Gorges Reservoir, China. Environmental Science \& Technology, 51(7), 3794-3801. DOI: 10.1021/acs.est.7b00369

Zhao, J., Ran, W., Teng, J., Liu, Y., Liu, H., Yin, X., Cao, R., Wang, Q. (2018). Microplastic pollution in sediments from the Bohai Sea and the Yellow Sea, China. Science of the Total Environment, 640-641, 637-645. DOI: 10.1016/j.scitotenv.2018.05.346 